\title{
COMPARATIVE ANALYSIS OF TRANSLATIONS PREPARED BY STUDENTS WITH AND WITHOUT LEGAL QUALIFICATIONS
}

\author{
MÁRTA LESZNYÁK, PhD \\ University of Szeged, Hungary, Faculty of Arts and Humanities \\ lesznyakm@t-online.hu \\ ORCID: https://orcid.org/0000-0002-9354-0633

\section{DORKA BALOGH, PhD Candidate} \\ Pázmány Péter Catholic University, Budapest, Hungary, \\ Faculty of Law and Political Sciences \\ balogh.dorka@jak.ppke.hu
}

ORCID: https://orcid.org/0000-0002-3849-3045

\begin{abstract}
In our paper, we present the results of the second phase of a study conducted in collaboration between two higher education institutions in Hungary with different types of translator training: a postgraduate (MA) course at the University of Szeged (SZTE), Faculty of Arts, and a postgraduate specialist training course at Pázmány Péter Catholic
\end{abstract}


University, Budapest (PPKE JÁK), Faculty of Law and Political Sciences. At SZTE, students do not have any legal qualifications, while at PPKE JÁK, students are all qualified legal professionals. Our main research question was whether there are significant differences in the quality of legal translations carried out by students with and without legal qualifications. We analyzed and evaluated the global (holistic) quality of the translations using a five-point scale as suggested by Kiraly (1995: 83), and compared types of errors made by the two groups of students with the help of a special error typology. Our results show that students with legal qualifications perform better in terms of both global and analytic indicators, with significantly less errors made in information transfer and in legal register.

Keywords: legal translation; legal translator training; error typology; analytical analysis; global analysis; English; Hungarian.

\title{
JOGI KÉPESÍTÉSSEL RENDELKEZŐ ÉS NEM RENDELKEZŐ HALLGATÓK FORDÍTÁSAINAK ÖSSZEHASONLÍTÁSA
}

\begin{abstract}
Hungarian: Az SZTE BTK Fordító- és Tolmácsképző Központja és a PPKE JÁK Deák Ferenc Intézete között 2015 tavasza óta folyik együttmüködés, melynek keretein belül a szakfordítóképzésben alkalmazott projektmódszer hatékonyságát és folyamatát vizsgáljuk. Kutatásunk központi kérdése az volt, hogy vajon a bölcsész végzettséggel rendelkező, mesterképzésben résztvevő hallgatók és a jogász képzettséggel rendelkező, szakirányú továbbképzésben résztvevő hallgatók angolról magyarra fordított szövegei között felfedezhetők-e különbségek. A különbségek alatt egyrészt globális, minőségi különbséget értettünk, egyszerübben fogalmazva: jobban fordít-e jogi szakszövegeket valamelyik csoport. Az értékeléshez a Kiraly (1995: 83) által kidolgozott öt-pontos skálát használtuk. Másrészt, az első kérdésre adott választól függetlenül felmerült a kérdés, hogy a két csoport által elkövetett hibák típusai mennyire különböznek egymástól, ezért analitikus elemzésre is sor került a Szegedi Tudományegyetemen használt javítási rendszer alapján általunk kialakított hibatipológia szerint. Eredményeink arra utalnak, hogy a jogász csoport egyértelmüen jobban teljesít a globális és az analitikus mutatók alapján is a bölcsészeknél. A bölcsész csoport esetében különösen szembeötlő a jogi szaknyelv-specifikus terminológia és regiszter hibák nagy száma, illetve az ezzel feltehetőleg összefüggésben álló információközvetítési problémák megjelenése.
\end{abstract}

Kulcsszavak: jogi szakfordítóképzés; projektmunka; hibatipológia; globális elemzés; analitikus elemzés; angol magyar. 


\title{
ANALIZA PORÓWNAWCZA PRZEKLADÓW DOKONANYCH PRZEZ STUDENTÓW Z KOMPETENCJAMI PRAWNYMI I BEZ NICH
}

\begin{abstract}
Abstrakt: W niniejszym artykule zostaną zaprezentowane wyniki drugiego etapu badania przeprowadzonego jako projekt wspólny dwóch jednostek szkolnictwa wyższego o różnych rodzajach kształcenia translatorskiego na studiach magisterskich: Uniwersytetu Szeged, Wydział Sztuki (SZTE) i specjalistyczne studia podyplomowe $\mathrm{z}$ zakresu przekładoznawstwa na Wydziale Prawa i Nauk Politycznych Katolickiego Uniwersytetu Pázmány Pétera w Budapeszcie (PPKE JÁK). Na SZTE studenci nie posiadają wykształcenia prawniczego, podczas gdy na PPKE JAK wszyscy uczestnicy to wykwalifikowani prawnicy. Głównym założeniem było sprawdzenie, czy istnieją znaczące różnice $\mathrm{w}$ jakości przekładu prawniczego przeprowadzonego przez studentów z i bez wykształcenia prawniczego. Przeanalizowano i oceniono jakość całościową (holistycznie) przy użyciu 5stopniowej skali Kiraly'ego (1995: 83) i porównano rodzaje błędów przy użyciu określonej typologii błędów. Badanie wykazało, że studenci z wykształceniem prawniczym wypadli lepiej w kategoriach ogólnych i analitycznych, przy znacznie mniejszej liczbie błędów popełnianych przy przekazywaniu informacji i rejestrze prawnym.
\end{abstract}

Słowa klucze: przekład prawny i prawniczy; kształcenie thumaczy prawnych i prawniczych; typologia błędów; analiza analityczna; analiza ogólna; język angielski; język węgierski.

\section{Introduction}

This paper presents the results of the second phase of an interinstitutional study that started in 2015. The project is being conducted in two different higher education institutions in Hungary (SZTE - the University of Szeged, Faculty of Arts, and PPKE JÁK Pázmány Péter Catholic University, Budapest, Faculty of Law and Political Sciences) at different educational levels: the postgraduate (MA) level at SZTE and the postgraduate specialist training programme level at PPKE JÁK. The MA level training is a 2-year, 4semester translator training programme, where students are not required to have any specialist legal knowledge at entry level, as legal translation constitutes only a part of their training. 
Márta Lesznyák \& Dorka Balogh: Comparative Analysis of ...

As for language knowledge, the entry requirements for this programme include at least one B2-level exam (in language C) and one C1-level exam (in language B). Whereas the students of the postgraduate specialist training programme are all qualified in law, and the entry requirement for their 3-semester training is a legal degree and a B2-level language exam.

Within the framework of the project, students had to translate three interconnected legal documents (a total of 15 pages) from English into Hungarian in teams of four or five. The exercise was done on four occasions (in the spring semester of 2015, 2016, 2017 and 2018) at both institutions. In the first phase of the research, we conducted an empirical study to examine the effectiveness and the advantages or possible drawbacks of the project method over individual translation in legal translator training (Balogh \& Lesznyák 2018), while in the second phase, we compared the quality of the translations prepared by the two different populations of students using global and analytic error-typologies, and analyzed the results by quantitative methods.

The main and long-term goal of this second phase was to identify the most frequent types of errors, draw methodological conclusions from the findings, and incorporate the experiences gained into the lesson plans and the curriculum of legal translator training to improve its effectiveness. It is important to note that, traditionally, most practising legal translators in Hungary have no legal qualifications, which they compensate with a lot of experience and a proven track record, having worked themselves into the subject thoroughly. However, as legal translation is gaining more and more ground, there is an increasing demand for legal translators with expert legal knowledge and excellent linguistic competence.

In order to provide methodological clues for the curriculum design of legal translator courses, we wanted to find out whether it is necessary to lay more emphasis on language development in the curriculum of translation students who are trained in law but not trained in languages, and, conversely, whether translation students who are not trained in law need more effective training in subject-field competence. While analyzing the results of the research, it became evident that questions of evaluation form an inherent part of the process, so we also processed and utilized findings related to quality assessment in legal translation. 
Based on the aims described above, we focused our research on the following questions:

1. Are there significant differences between the quality of translations (EN-HU) prepared by MA students of humanities without legal qualification and students with legal qualification attending a postgraduate specialist course?

2. Which group's translations better satisfy the requirements of professional legal translation in a global sense?

3. What error types are characteristic of each sub-sample?

4. Is there a relationship between the frequency of the error types and the general quality of the translations?

\section{Theoretical background}

It has been argued by several researchers of translation that knowledge of the special fields of translation has an impact on the quality of the translation. Kiraly (2005) argues that insufficient knowledge of specialized fields and terminology is one of the major difficulties faced by translation graduates. Northcott and Brown (2006: 374) suggest that translators should "learn to 'think like lawyers' in order to understand legal texts". According to Šarčević (1997), the ideal legal translator should possess in-depth knowledge of legal terminology (meaning that they are aware of the conceptual references of terms relative to the legal culture they are used in), and, at the same time, should be familiar with the mechanism of the law (to understand legal reasoning, be able to analyze legal texts, predict how a text will be interpreted, or applied by a court, etc.). Trosborg (1998) points out that if translators want the text to fulfil its function in a given professional community, they have to be aware of the stylistic features of the genre. In her view, register manifests itself in syntax and collocations rather than lexical units. Bhatia (1997) concludes that linguistic competence is not enough to preserve the generic identity of the target text; it has to be complemented by sufficient knowledge of the two code systems (i.e. legal systems) and the competence to acquire and apply generic knowledge. Alcaraz and Hughes (2002) argue that translations will not be authentic without the translator recognising the given genre and recreating 
it according to the generic rules applied in the legal culture of the target text. In a similar vein, in his legal translation competence model, Prieto Ramos (2011) situates comparative legal skills at the core of the thematic subcompetence, and stresses that translation and legal knowledge are inextricably linked throughout the (legal) translation process.

It seems logical to conclude from the observations above that (legal) translation courses designed for students who are not trained in law cannot avoid integrating legal content into their syllabi at some stages of the course. As in Hungary the Act on Higher Education provides for a limited number of lessons in translator training programmes, integrating legal content into the curriculum poses a major challenge, especially for the programmes that train translators not only in law, but also in other social sciences. Furthermore, although much has been written about ways to improve the subjectfield competence of legal translation students, little has been said about the opposite: how to plan a course in the case of translation students who possess legal qualifications, but lack the sufficient linguistic background - that is, how to avoid the risk of the legal translation course turning into an advanced level language class, as Nord (1991) warns against. Prieto Ramos (2011:19) also highlights this dichotomy when he points out that students with a

\footnotetext{
"... legal background can be expected to have a very strong thematic competence $[\ldots]$, but also important deficiencies in key linguistic, textual and strategic competences; whereas the reverse might be the case for translation graduates".
}

In both cases, very careful planning is needed to decide on the proportions, the weighting and the method of integrating either language classes or lessons on law into the curricula of translator training courses.

The cooperation between the authors of this study offered an opportunity to test the strength of the arguments quoted above, as we were both teaching legal translation to two different groups: one with a legal background, but without having studied linguistics, and the other with a linguistic background, but without legal knowledge. Is there really such a big difference between their performance? If yes, what are the areas that need to be improved more efficiently? These were some of the questions we attempted to answer 
when we categorized and compared the errors students made in their translations, with the help of an analytic error typology.

\subsection{Analytic error typology used for the comparison and evaluation of translations}

Although some literature is available on legal translation quality assessment (e.g. Leung, 2014, Prieto Ramos 2015), we could not find any detailed error typology for legal translations that could be used in training. As a result, we developed an analytic error typology that is based on the evaluation standards applied in our own institutions, in which we applied common aspects of translation evaluation to legal translation. When distinguishing between the types of errors, we had to keep in mind the fact that increasing the number of error types would also increase the difficulty of the evaluation of the results, so we finally decided on distinguishing between seven types of errors, which proved to be a reasonable choice. We marked the error types with different colours, and corrected the translations by using these colour codes. Five of the seven error types are matched to language levels, so that identification of the exact area (level of language) to be further improved is made easier. Errors in language usage were related to the level of morphology and syntax, errors in terminology (within this category legal terminology and the terminology of the subject matter of the given legal document were separated) were matched to the semantic level, while errors in legal (genre-specific) and non-legal register were matched to the pragmatic level of language. In addition to these, two further aspects (orthography and distorted information content) were introduced to measure general professional presentation (layout, spelling, hyphenation, capitalization, punctuation, etc.) and errors in the transfer of information. No specific language level was matched to these, as the first one (layout and orthography) covers a much broader area than phonology, while the second one (distorted information content) refers to errors distorting information due to reasons other than those presented under the former categories, and such errors may manifest themselves at any level of language. The typology is presented in Table 1 below. 
Márta Lesznyák \& Dorka Balogh: Comparative Analysis of ...

Table 1. Analytic error typology by error units corresponding to linguistic levels

\begin{tabular}{|c|c|c|}
\hline Type of error & Language level & Explanation/Examples \\
\hline $\begin{array}{l}\text { layout and } \\
\text { orthography }\end{array}$ & not relevant & $\begin{array}{l}\text { shortcomings in the overall } \\
\text { professional presentation of the text, } \\
\text { plus errors in spelling, hyphenation, } \\
\text { capitalization, word breaks, } \\
\text { emphasis, and punctuation }\end{array}$ \\
\hline $\begin{array}{l}\text { errors in } \\
\text { language } \\
\text { usage }\end{array}$ & $\begin{array}{l}\text { morphology and } \\
\text { syntax }\end{array}$ & $\begin{array}{l}\text { inappropriate word forms, } \\
\text { inaccurate use of modifiers, } \\
\text { inaccurate word order, etc. } \\
\text { Example: English original: every } \\
\text { third party; inaccurate Hungarian } \\
\text { translation: minden harmadik felek; } \\
\text { English gloss: every third parties }\end{array}$ \\
\hline $\begin{array}{l}\text { inaccurate use } \\
\text { of non-legal } \\
\text { terminology }\end{array}$ & semantics A & $\begin{array}{l}\text { use of inappropriate terminology } \\
\text { related to the subject of the legal } \\
\text { document } \\
\text { Example: English original: monthly } \\
\text { progress report; inaccurate } \\
\text { Hungarian translation: havi } \\
\text { helyzetjelentés; English gloss: } \\
\text { monthly situation report }\end{array}$ \\
\hline $\begin{array}{l}\text { inaccurate use } \\
\text { of legal } \\
\text { terminology }\end{array}$ & semantics B & $\begin{array}{l}\text { use of inappropriate legal } \\
\text { terminology } \\
\text { Example: English original: } \\
\text { remuneration; inaccurate Hungarian } \\
\text { translation: kártérités; English gloss: } \\
\text { indemnification }\end{array}$ \\
\hline $\begin{array}{l}\text { inaccurate use } \\
\text { of legal } \\
\text { register and } \\
\text { genre-specific } \\
\text { language }\end{array}$ & pragmatics A & $\begin{array}{l}\text { inaccurate use of standard phrases } \\
\text { and collocations used in the context } \\
\text { of legal genres (contracts, in this } \\
\text { case) } \\
\text { Example: English original: parties } \\
\text { are reciprocally liable; inaccurate } \\
\text { Hungarian translation: felek forditva } \\
\text { felelösek; English gloss: parties are }\end{array}$ \\
\hline
\end{tabular}




\begin{tabular}{|c|c|c|}
\hline & & liable the other way round \\
\hline \multirow[t]{2}{*}{$\begin{array}{l}\text { inaccurate use } \\
\text { of non-legal } \\
\text { register }\end{array}$} & pragmatics B & $\begin{array}{l}\text { inaccurate use of collocations and } \\
\text { standard phrases not related to the } \\
\text { legal register }\end{array}$ \\
\hline & & $\begin{array}{l}\text { Example: English original: (carry } \\
\text { out the works) directly; inaccurate } \\
\text { Hungarian translation: direkt } \\
\text { módon; English gloss: in a direct } \\
\text { way }\end{array}$ \\
\hline \multirow[t]{2}{*}{$\begin{array}{l}\text { errors in } \\
\text { information } \\
\text { transfer }\end{array}$} & not relevant & $\begin{array}{l}\text { information distorted due to reasons } \\
\text { other than those listed in the above } \\
\text { categories (e.g. incomprehensible } \\
\text { sentences; omission of information } \\
\text { or adding extra information without } \\
\text { any reason; problems with cohesion } \\
\text { and coherence) }\end{array}$ \\
\hline & & $\begin{array}{l}\text { Example: English original: [this } \\
\text { framework agreement]... will be } \\
\text { implemented through specific deeds; } \\
\text { inaccurate Hungarian translation: a } \\
\text { benneraberszödésben] } \\
\text { foglaltakat meghatározott feltételek } \\
\text { mellett teljesitik. English gloss: [this } \\
\text { framework agreement]... will be } \\
\text { implemented under specific } \\
\text { conditions. }\end{array}$ \\
\hline
\end{tabular}

\subsection{Global quality assessment}

In order to answer research question 2 (which group's translations better satisfy the requirements of professional legal translation in a global sense?), the global quality of the translations was also assessed on a five-point scale (Kiraly 1995: 83), as presented in Table 2 below. 
Márta Lesznyák \& Dorka Balogh: Comparative Analysis of ...

Table 2. Five-point scale of global quality assessment of translation (Kiraly 1995: 83)

\begin{tabular}{|l|l|}
\hline $\begin{array}{l}\text { Scale } \\
\text { rank }\end{array}$ & Description \\
\hline 1 & This is a totally unacceptable translation. \\
\hline 2 & This is a poor translation. \\
\hline 3 & $\begin{array}{l}\text { This translation is marginally adequate. It has several errors and } \\
\text { would require a moderate amount of work to prepare it to be } \\
\text { submitted to any employer. }\end{array}$ \\
\hline 4 & $\begin{array}{l}\text { This is basically a good translation. It does have some minor } \\
\text { error, but they could be eliminated quite easily. }\end{array}$ \\
\hline 5 & $\begin{array}{l}\text { This is a very good translation. It contains no errors with respect } \\
\text { to the norms of the TL and it is a functionally acceptable } \\
\text { translation of the source text. }\end{array}$ \\
\hline
\end{tabular}

\subsection{Hypotheses related to error types}

It is important to note here that the following hypotheses were formulated with two specific populations of translation trainees in mind: one population consists of humanities students who lack training in law, and the other population is made up of legal professionals who have not taken part in any kind of linguistic training. The two groups will be characterized in more detail in the next section.

Drawing on the research findings mentioned above and also on our experience as legal translator trainers, we were not expecting any significant differences in the case of the first type of error (layout and orthography), as the observation of these requirements does not depend on professional training, but rather on general language skills in language A (which were assumed to be largely similar for both groups) and the attentiveness of the individual. Also, both groups were expected to monitor their work and run the spell check. 
Layout, if handled separately, might even be an area where legal professionals make fewer errors than their not legally qualified counterparts, as in their profession they are conditioned to respect the formal elements of documents.

With regard to the second type of error (language usage), we presumed that legal professionals would make slightly more errors than students of humanities, as their language awareness might not be at the same level. We presumed that there would be larger differences in the number of these errors, should the direction of the translation be different (HU-EN instead of EN-HU).

The third type of error denotes the inaccurate use of non-legal terminology. Although some typologies handle lexicography as a separate level of language representation, we decided to match terminology to the semantic level of language, as in the case of translation, the meaning of terms is the decisive factor. This error type refers to use of inappropriate terminology related to the subject of the legal document. As the law covers all areas of life, legal translators are faced with the extra challenge of tackling various kinds of specialist vocabulary, which, in the case of this text, was the terminology of architecture and the construction industry. In this respect, we presumed that legal professionals and non-legal professionals would make approximately the same number of errors.

The fourth type of error refers to the inaccurate use of legal terminology. Since the task was to produce a text in its own right (see the description of the translation task under 3.2) and to adapt it to the drafting conventions of the target culture (i.e. Hungarian), it was important that students recognize and apply the appropriate translation strategies in cases of partial equivalence or nonequivalence. In legal translation, being aware of the conceptual meaning behind terms and deciding on such transfer strategies is crucial, as a bad choice of terminology might result in the failure of conveying the message of the text, which also means that the intended function of the target text might not be realized. We presumed that, partly due to the lack of systematic legal training, students of humanities would make more errors of this type than legal professionals. This is because students of humanities often have problems recognizing the "traps" (such as e.g. ambiguities) posed by legal terms or legal texts in general, even if they are trained in methodology and are made aware of translation strategies for reformulation. A possible explanation for that, in cases 
of insufficient thematic training, is that they lack the foundations to navigate between legal systems and to see beyond the surface (i.e. to adopt the legal reasoning of legal professionals).

The fifth type of error (inaccurate use of legal register and genre-specific language) is related to the pragmatic level of language. It includes inaccurate use of standard phrases and collocations used in the context of legal genres, in the present case, contracts. Familiarity with the set phrases used in contracts both in the source and the target language is again a crucial requirement. In more serious cases, a lack of this knowledge might lead to the impairment of the function of the document, which might have legal consequences, while in less serious cases the message might come through, but the text might become clumsy and unprofessional. In this respect, we presumed that students of humanities would make more errors than legal professionals.

The sixth error type denotes inaccurate use of non-legal register, and includes, inter alia, errors related to the inappropriate use of collocations. According to our presumptions, legal professionals and non-legal professionals would make approximately the same number of errors in this respect.

The final type of error refers to distorted information content. All the other types of errors listed might entail distortion of information, but in this typology the primary aspects of consideration were the attributes defined under each of the categories. Thus, this unit refers to information distorted due to reasons other than listed in the above categories (e.g. incomprehensible sentences; omission of information or adding extra information without any reason; problems with cohesion and coherence). These errors necessarily result in the breakdown of information transfer, implying that the communicative function of the document is not performed. In this category, we expected students of humanities to perform better than their legal professional counterparts, as these types of errors are primarily related to language usage.

Thus, taking into account both the possible shortcomings in the global quality of the translations and the errors distinguished in the analytic error typology, our final hypotheses were the following: 
1. There will be differences between the global quality of translations prepared by students with and without legal qualifications.

2. Professional knowledge and experience will be an advantage for legal professionals (and improve the quality of their legal translations), while the lack of these will be a disadvantage for students of humanities.

3. The proportion of certain error types will diverge by student group (students with and without legal qualifications), as follows:

- Legal professionals and non-legal professionals will probably make approximately the same number of errors in layout and orthography.

- At the morphological and syntactical levels of language, legal professionals will make slightly more errors than students of humanities.

- At semantic level "A" (inaccurate use of non-legal terminology), legal professionals and non-legal professionals will make approximately the same number of errors.

- At semantic level "B" (inaccurate use of legal terminology), students of humanities will make significantly more errors than legal professionals.

- At pragmatic level "A" (inaccurate use of legal register and genre-specific language), students of humanities will make significantly more errors than legal professionals.

- At pragmatic level "B" (inaccurate use of non-legal register), legal professionals and non-legal professionals will make approximately the same number of errors.

- Legal professionals will make more errors than students of humanities in the transfer of information due to reasons other than listed above (such as incomprehensible sentences, omission of information or adding extra information without any reason, and problems with cohesion and coherence). 
Márta Lesznyák \& Dorka Balogh: Comparative Analysis of ...

\section{Methods and Materials}

\subsection{The participants}

The two groups of students described in the introduction, that is legal professionals participating in specialized translator training and postgraduate students participating in an MA programme in translation and interpreting, produced the target texts which were analyzed. At the time of the data collection, the legal professionals had passed, at least, a B2-level language exam in English, and the postgraduate students had obtained their first degrees in humanities, mostly in foreign languages. Entry requirements for the MA programme include at least one B2-level exam (in language $\mathrm{C}$ ) and one C1-level exam (in language $\mathrm{B}$ ). In consequence, at least half of the humanities students had passed a C1-level exam by the time of the data collection. No data was collected about the age of the participants, but simply because of the length of previous training (law school vs. BA studies), legal professionals were slightly older and had more work experience than the MA students. The postgraduate course for legal professionals is a three-semester course and the students were in their $2^{\text {nd }}$ semester when they participated in the study. The MA students were in the last $\left(4^{\text {th }}\right)$ semester of their studies when they took part in the research. Parallel to the legal translation course, MA students also had a course on the "Basics of Law".

In the framework of the study, 5 translations from each group were analyzed, that is 5 translations from legal professionals and 5 translations from MA translation students with a background in humanities/languages. The reason behind this is that within the two years of the investigation, the legal professionals produced only five group translations as there are relatively few students taking part in specialized translator training. It is important to stress here that the translations were made in groups. The MA students, on the other hand, produced 14 translations within the two years, out of which 5 were chosen for analysis by one of the researchers, who was also their trainer. The aim of the selection was to reflect the humanities population's performance as accurately as possible; as a result, 
the criterion for selection was to make sure and include all levels of performance in the sample. To ensure this, the trainer examined humanities students' previous performance in the legal translation course and identified high achievers, average achievers and low achievers on the basis of the scores they received for their translations. Next, the composition of the groups was examined and translations from high ability, low ability and mixed ability groups were included in the sample. It should be noted here that in the first year of the project, students formed groups themselves which led to a large number of homogeneous groups. This practice was changed in the later years for pedagogical reasons.

\subsection{The translation task and the target texts}

Within the framework of the project, students had to translate a fifteen-page long agreement made up of three parts. In the agreement, an Italian company subcontracted another Italian company to carry out the renovation of a hotel in Budapest. The parties to the contract were Italian, and consequently, the law applicable to the contract was also Italian. The reason why the text had to be translated into Hungarian was that the construction work that the parties contracted for was to be carried out in Hungary, and some of the authorities issuing permissions required the documentation to be submitted in Hungarian. Consequently, the expected translation strategy can be regarded as instrumental as defined by Nord (1997), meaning that the target text had to be adapted to the generic conventions of contracts used in Hungary and apply the special terminology and register of contracts accordingly. This was made clear to students in the translation brief. The task was authentic, since one of the authors had been assigned with the translation of the text some years earlier.

It is very difficult to assess the difficulty of a translation task as yet, we have no objective tools or measures to do so. However, both authors are of the opinion that this task was undoubtedly difficult. The source text was originally drafted in Italian, and then translated from Italian into English by Italians, as a result, the text 
included many unusual phrases and structures which made it difficult to understand and identify legal terms and phrases, as they were not always formulated in standard legal English (examples include IVA instead of VAT, Chamber of Commerce, Industry, Handicrafts and Agriculture in Budapest - an institution not existing in such a form). In addition, due to its non-native nature, the source text contained some other types of language errors. Another difficulty arose from the subject of the agreement, which required a certain level of understanding architectural and engineering concepts and the competence of using appropriate terminology.

However, as the aim of the project was to simulate real-life translation assignments (and indeed, this text was a previous assignment) and as both groups were close to graduation, it was decided that the source text serves the pedagogical and the research purposes of the project well. In our experience, texts written in "lingua franca" English (i.e. non-native English) to be translated into Hungarian are fairly typical in real translation assignments, and translation students need to be prepared for strategies to cope with the challenges posed by such texts.

\subsection{The sample}

To evaluate and analyze ten times 15 pages would not have been feasible or economical. Therefore, a sample of two articles (one and a half pages, approximately $10 \%$ of the text) was chosen for analysis (this ST segment can be found in Appendix 1).

The target texts were evaluated by two independent raters (the two authors). To ensure objective, blind and anonymous evaluation, the ten texts were put in random order and renamed by an independent person. New filenames contained only numbers (from 1 to 10), and the key for the later identification of the texts was saved in an excel file (by the same independent person). Figure 1 shows the screenshot of the directory that contained the files (texts) to be evaluated. It can be clearly seen that the evaluators could not identify which translation came from which group. 
Figure 1. Screenshot of the directory containing the translations to be evaluated

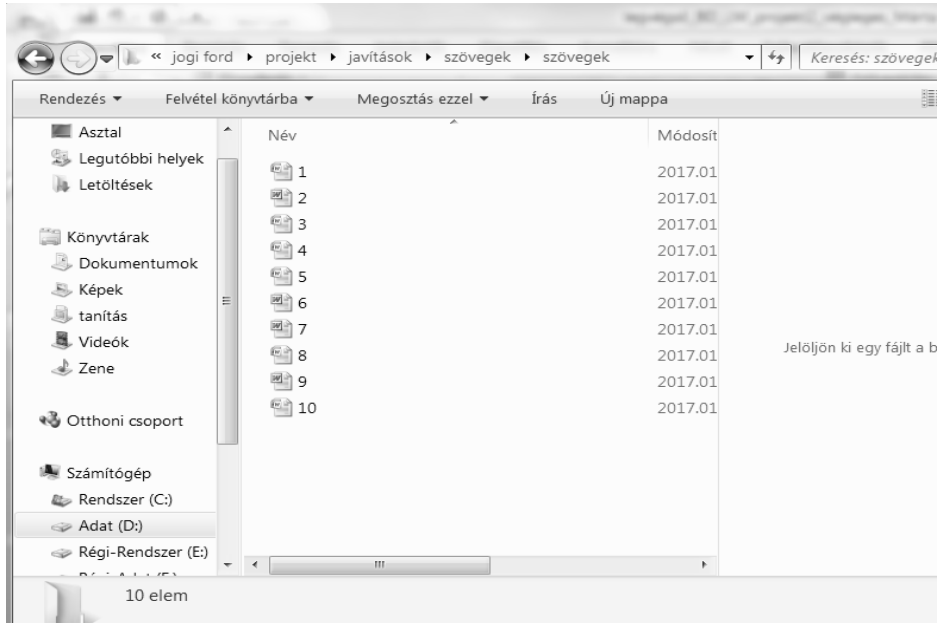

\subsection{Data collection}

The translations were produced in the Academic Years of 2014/15 and 2015/16 within the framework of a pedagogical project embedded in a legal translation course. Within the project, students worked in teams of three or four, allocating the roles of project manager, terminologist, proofreader and/or editor between themselves. They were also given the freedom to divide the text between themselves, which meant that in some cases proofreaders only translated one or two pages of the whole text, as they had to go through the whole translation. Each group had a terminologist, who was responsible for terminological coordination. After submitting the finalized translations to the clients (the trainers), each team had to proofread the translation of another team. All through the work, students were required to keep a translation journal, and present their most interesting findings in a ppt presentation at the end of the project.

The evaluation of the selected segments took place in January 2017. 


\subsection{The pre-evaluation phase: piloting the error typology, training the raters}

The aim of the pre-evaluation phase was to test the error typology, on the one hand, and, on the other hand, to help raters align their criteria, thus contributing to higher interrater agreement and reliability.

As a first step in this process, an article of the contract other than the ones selected for the study was chosen for piloting the error typology. The two evaluators working independently evaluated this segment with the help of the first version of the error typology. Next, the raters discussed and analyzed the results of the evaluation. Differences in error category judgments led to discussions and clarifications of what error categories involve. As an outcome of this phase, two error categories were split into two, which led to an increase in the number of error categories. More specifically, register errors were divided into legal and non-legal register errors, and terminology errors were divided into legal and non-legal terminology errors. After agreement was reached on error categories and disputed text segments, the raters agreed to start the evaluation of the designated articles, but it was also decided that, after analyzing text 1 , another discussion session would take place to further harmonize the raters' judgments. As a result of these final preparatory phases, criteria were further clarified and, in some cases, correct solutions (i.e. the only acceptable solutions) were identified (e.g. legal or engineering terms).

\subsection{Evaluation phase and data analysis}

The evaluation of the selected articles was carried out in strict order by both raters (from text 1 to text 10). Global evaluation scores were given spontaneously while reading and evaluating the translations but, in all cases, before completing analytical error identification. Global and analytical scores were recorded in an Excel file and were submitted to statistical analysis. 


\section{Results}

\subsection{Interrater agreement and reliability}

As translation is a complex, open-ended task that has no one correct solution, evaluation always involves a subjective component. As a result, interrater agreement and reliability must be checked to ensure objectivity and reliability in evaluation. In this study, ordinal scales (global assessment) and interval scales (error numbers) were used for evaluation; consequently, interrater reliabilities were expressed though consensus estimates (percent agreements) and consistency estimates (correlation coefficients). Although there is some controversy in the literature, consistency estimates above 0.6 are usually considered to be acceptable, and values above 0.8 are interpreted as excellent (Stemler and Tsai 2008: 38).

Table 3 shows the global evaluation scores for each translation by raters. As can be seen, interrater agreement was high: of the 10 texts, there was complete agreement on all but two, where there was a one and two point discrepancy. As a consistency estimate, Spearman rho was calculated, the value of which $(0.86, \mathrm{p}<0.01)$ also indicated high interrater consistency. These estimates suggest that global evaluation is very reliable, the raters' judgments are identical or are very close to each other.

Table 3. Global evaluation scores

\begin{tabular}{|l|l|l|}
\hline ID number of TT & Rater $\mathbf{1}$. & Rater $\mathbf{2}$. \\
\hline 1 & 3 & 3 \\
\hline 2 & 5 & 3 \\
\hline 3 & 4 & 4 \\
\hline 4 & 1 & 1 \\
\hline 5 & 2 & 3 \\
\hline
\end{tabular}


Márta Lesznyák \& Dorka Balogh: Comparative Analysis of ...

\begin{tabular}{|l|l|l|}
\hline 6 & 5 & 5 \\
\hline 7 & 3 & 3 \\
\hline 8 & 2 & 2 \\
\hline 9 & 4 & 4 \\
\hline 10 & 1 & 1 \\
\hline
\end{tabular}

If we now turn to analytical evaluation, we find that Pearson $\mathrm{r}$ (expressing interrater consistency) for the total number of errors was $0.65(\mathrm{p}<0.5)$. This suggests that the total error number is an acceptable but less reliable indicator of performance than the global score. In other words, the number of errors identified by the individual raters was very similar but agreement was lower than for global evaluation.

Interrater reliability was also checked for the individual error types. However, a significant correlation between the raters (i.e. interrater consistency) was only found for information transfer errors $(r=0.95 ; \mathrm{p}<0.001)$.

This led us to the conclusion that even after lengthy preparation and training, the agreement between the raters on identifying error types was not satisfactory. A possible explanation for this is that, in most cases, it is very difficult to draw a clear line between error types. The only exception is information transfer error, which, by its very nature, is dichotomic (transferred information: yes/no, true-false), as a result, uncertainties in categorization are less likely to occur. It should be stressed here, however, that agreement between the raters on error numbers was satisfactory, even if the same error was often put into different categories by the two raters. The small sample size could also contribute to low correlation between the raters. 


\subsection{Differences between legal professionals and students of humanities}

Table 4 and Table 5 compare students of humanities and legal professionals on global performance measures and on error numbers. In addition to mean scores, results of independent samples t-tests are shown in the tables. Close examination of the figures shows that in contrast to many of our hypotheses - whenever there are significant differences between the two groups, legal professionals always outperform students of humanities. Their global performance scores are significantly higher, and they made significantly less information transfer and register (legal and non-legal) errors. What is striking about the figures in the tables is that the differences between the two groups are not only statistically significant, but also quantitatively marked: on the 5-point global scale, a 2-point difference between the two groups is remarkable. Similarly, humanities students made, on the average, 30-40 more mistakes in their translations than legal professionals, out of which 10-15 were information transfer errors. It must be added, however, that no significant differences were found on language, orthography and terminology.

The number of legal register errors in humanities students' translations is somewhat lower than the number of information transfer errors, but these errors make their texts sound unprofessional. Some examples to illustrate the errors students of humanities have made in terms of register are: the contract says (instead of the contract stipulates); they have the right (instead of they are entitled); the parties are responsible the other way round (instead of the parties are reciprocally responsible/liable). Possible explanations for these findings will be given in the next section. 
Márta Lesznyák \& Dorka Balogh: Comparative Analysis of ...

Table 4. Differences between humanities students' and legal professionals' global scores (results of independent samples t-tests)

\begin{tabular}{|l|l|l|l|l|}
\hline & $\begin{array}{l}\text { Students of } \\
\text { humanities }\end{array}$ & legal professionals & $\mathbf{t}$ & $\mathbf{p}$ \\
\hline Rater 1 & 1.8 & 4.2 & -4.54 & $<0.01$ \\
\hline Rater 2 & 2 & 3.8 & -3.09 & 0.16 \\
\hline
\end{tabular}

Table 5. Significant differences between humanities students and legal professionals error numbers (results of independent samples t-tests; $\mathrm{n} . \mathrm{s}=$ non-significant)

\begin{tabular}{|l|l|l|l|l|l|}
\hline & & $\begin{array}{l}\text { Students of } \\
\text { humanities }\end{array}$ & $\begin{array}{l}\text { legal } \\
\text { profess } \\
\text { ionals }\end{array}$ & $\mathbf{t}$ & $\mathbf{p}$ \\
\hline $\begin{array}{l}\text { Total number of } \\
\text { errors }\end{array}$ & rater 1 & 61 & 21 & 6.58 & $<0.01$ \\
\hline $\begin{array}{l}\text { Information } \\
\text { transfer error }\end{array}$ & rater 1 & 20.8 & 6.4 & 4.6 & $<0.01$ \\
\hline & rater 2 & 20.6 & 11.2 & 3.55 & 0.01 \\
\hline $\begin{array}{l}\text { non-legal } \\
\text { register error }\end{array}$ & rater 1 & 7.2 & 1.6 & 3.96 & $<0.01$ \\
\hline & rater 2 & 10 & 4.8 & 2.94 & 0.019 \\
\hline $\begin{array}{l}\text { legal register } \\
\text { error }\end{array}$ & rater 1 & 15.6 & 4 & 4.08 & $<0.01$ \\
\hline & rater 2 & 9.4 & 3 & 2.08 & $\begin{array}{l}0.09 \\
\text { n.s }\end{array}$ \\
\hline
\end{tabular}




\subsection{The relation between the perceived global quality of the translation and the number of error types}

One of our research questions focused on the relation between global evaluation and error numbers/types; in other words, what types of error seem to be related to the impression a target text makes. Correlation analyses indicated that it is information transfer errors that show the highest correlation with global assessment scores for both raters $(r=-0.97$ and $r=-0.90 ; p<0.01)$. For one of the raters, legal and non-legal register errors and non-legal terminology had significant negative correlations with global scores, too.

\section{Discussion of the results and limitations}

When interpreting the above results, it must be taken into account that the sample size was relatively small, which might have led to non-significant findings. In addition, even if some of the correlations and tests are significant, the generalizability of the findings is limited because of the small sample size.

With respect to our hypotheses (see Section 2.3), we found that Hypotheses 1 and 2 were confirmed by our results, that is, there were differences between the two studied groups (Hyp. 1), and subject competence emerged as a clear advantage (Hyp. 2). However, Hypothesis 3 had to be partly rejected: previous studies in foreign languages did not provide any advantage to humanities students, and as a result, there were no categories where they made fewer errors.

In more detail, the figures in the previous section suggest that there are considerable differences between the performance of humanities students and legal professionals when it comes to translating legal texts in the case of the groups analyzed. Legal professionals outperformed humanities students and the magnitude of the differences is daunting. On the global scale, legal professionals had a mean score of 4 (on a 5-point scale), which means that even if the translations contained some mistakes, they were acceptable. On the same scale, the humanities students' mean score was around 2, 
indicating that the average translation was not even worth editing and proofreading.

In line with the results of the global assessment, the analytical evaluation showed that legal professionals make considerably less mistakes than humanities students. Differences were significant and remarkably large for global error numbers and for information transfer errors. The high number of information transfer errors (mean values around 20 by each rater in the one and a half page text) committed by humanities students is particularly alarming, because mistranslations in legal texts may have serious consequences.

Personal experiences of the authors suggest that instructor feedback alone might not be enough to raise students' awareness concerning the quality of their work. Students instinctively compare themselves to each other and when group averages are low they may not realize that even students better than the norm are, in reality, very weak. Warning remarks from the instructor are often dismissed in situations like this, because the reality of the students (i.e. group norm) suggests that there are, in fact, high achievers/good translators in the group. As a result, instructors themselves try to avoid giving too much negative feedback, simply because it is not effective and may backfire. A much better solution would be to mix legal professionals and humanities students - at least, in part of their training, in some classes so that they can learn from each other.

It is not very surprising that humanities students made a large number of legal register errors as opposed to legal professionals. For a layperson, this can be the most striking difference between the texts of humanities MA students and those of legal professionals: humanities students' target texts as a whole do not create the impression of professional legal texts even if most of the terminology is used correctly and even if information transfer mistakes are relatively low. The reason behind this is their inexperience with the legal register. We assume that the legal register is learnt by legal professionals mostly implicitly during their studies and internships, when they are required to read and produce large amounts of texts. They might get corrected but it is not very likely that rules of language use are explicitly explained to them. There is no way for humanities students to make up for all these years of implicit learning law students experience within a few months (the length of a legal translation course). 
It is less clear why humanities students made a larger number of general (non-legal) register errors than legal professionals. Unfortunately, there are no empirical research results on translator trainees' register use in the mother tongue, but the authors have the impression that students, particularly MA students very often struggle with register. A possible explanation is that they usually have a BA degree in a modern foreign language indicating that they have not used their first language for studying and for reading and writing formal texts for a couple of years. This basically means that written language development gets (temporarily) interrupted at the age of 18 in the first language, with the outcome that many students do not even realize that registers exist. Some of them even have difficulties with adhering to formal language throughout a text. This phenomenon can be reflected in the high number of non-legal register errors in our study.

At the same time, it is possible that the translation was cognitively so demanding for the MA students (with the nonnative text, ideas and concepts of relatively unknown fields [law and architecture], their interrelations and the professional terms used for them) that no processing capacity was left for relatively simple register issues, and as a result, text production in its entirety broke down. In other words, with the backdrop of a highly demanding text, students could not handle segments that they might have been able to translate appropriately in other easier contexts.

It can be somewhat surprising that no significant differences were found between the two groups on terminology use (legal and non-legal). This result may be explained by the fact that, in many cases, terms (as opposed to features of register) can be defined more clearly; their meanings, use and boundaries are often more clear-cut, and exhaustive lists can be compiled of them. As a result, they lend themselves very well to explicit teaching and they are easier to recognize and learn than register, which tends to be fuzzier. Consequently, by the time humanities students started the translation project, they had already got acquainted with a large number of legal terms. In addition, students in their final semester had acquired skills and techniques of recognizing terms in the source text and researching their possible equivalent or reformulation in the target language. 


\section{Conclusions and suggestions for further research}

The aim of our study was to compare the performance of two groups of translation students, that of legal professionals and that of MA students with a background in modern languages/humanities, when given a project-based legal translation task. As only 10 translations (5 from each group) were compared, no definite conclusions can be drawn from our findings; we would rather argue that our results can be thought of as hypotheses for further research on larger samples and in other cultural and educational contexts.

Nevertheless, our study revealed significant differences between the performance of the two groups: legal professionals were more precise and their language use was more appropriate than that young humanities students. A limitation of the study is that it was carried out with translation students; as a result, findings cannot be generalized to professional translators. It is also possible that translators with a modern language/humanities background (BA degree) compensate for their deficiencies in the long run, and become excellent legal translators. What our study shows is that they start with a disadvantage.

A particularly alarming finding was the low performance of MA translation students just two months before graduation. The low global quality and the large number of errors (particularly information transfer errors) suggest that they are not ready to accept legal translation assignments, although with their degree in their hands, they could do so. The phenomenon raises several questions: is a semester-long course (both in basics of law and legal translation) enough for students to learn how to do legal translations? If not, what should be done about it? How much time would humanities students need to develop an acceptable level of competence in legal translation? Are there any teaching methods that could speed up the learning process? A possible solution to training legal translation students without legal qualification could be the integration of law courses in their translator training programmes in the form of interdisciplinary training, as suggested by Prieto Ramos (2011), who is of the view that comprehensive training may produce legal translators as competent as those who have a double parallel qualification in translation and law. Orlando (2015) also comes to the conclusion that a parallel education in both law 
and languages/translation can be advisable for the training of legal translators. However, in Hungary, there is currently no opportunity to combine translation courses with law courses within the framework of MA programmes. As a result, if translators with no legal qualifications decide to specialize in legal translation, they may need further training and mentoring. Alternatively, a certification process could be introduced to assure quality in legal translation.

In this study, translation from language $B$ to language A was assessed. Taking into consideration that inverse translation, that is translation from language $A$ to language $B$, is extensively practiced and therefore important in countries whose languages are not widely spoken (see also Ferreira and Schwieter 2017), it could be relevant to examine whether legal professionals have the same advantage in inverse translation in such settings. As humanities students' language proficiency in their B language is theoretically higher than that of legal professionals, the magnitude of differences could be smaller or non-existent.

The present study could also be repeated with other legal genres. It could be hypothesized that different legal genres pose different degrees of challenge to those not trained in law. Contracts with their complex and partly archaic language could be one of the most difficult legal genres to translate. Consequently, extrapolating our findings to other text types should be done with caution.

Finally, our study highlighted certain problem areas in the training of translation students in a general programme. Notably, the large number of register errors and information transfer error suggest that training should focus on helping students gain a better understanding of law, or at least, basic legal concepts and acquire "legal language". As these aims are already included in the curriculum, methodological innovations are needed to improve teaching, and new methods should be tested with classic experimental research design, involving experimental and control groups. 
Márta Lesznyák \& Dorka Balogh: Comparative Analysis of ...

\section{Bibliography}

Alcaraz Varó, Enrique and Brian, Hughes. 2002. Legal Translation Explained. Manchester: St Jerome.

Balogh, Dorka and, Márta, Lesznyák. 2018. Project work in the legal translation classroom: First results of an empirical investigation. In Latest Trends in Hungarian Translation Studies, ed. Ildikó Horváth, 173-190. Budapest: Hungarian Office for Translation and Attestation Ltd. (OFFI).

Bhatia, Vijay Kumar. 1997. Translating Legal Genres. In Text Typology and Translation, ed. Anna Trosborg, 203-214. Amsterdam, Philadelphia: John Benjamins.

Ferreira, Aline, and John, Schwieter. 2017. "Directionality in translation." In The Handbook of Translation and Cognition, eds. Schwieter, John and Aline Ferreira. 90105. New York: John Wiley \& Sons.

Leung, Matthew. 2014. Assessing Parallel Texts in Legal Translation. Jostrans $\quad 1$ : 89-105. (online: https://www.jostrans.org/issue01/art_leung.php)

Kiraly, Donald C. 2005. Project-based learning: A case for situated translation. Meta: Journal des traducteurs / Meta: Translators' Journal 50(4): 1098-1111.

Nord, Christiane. 1991. Text Analysis in Translation. AmsterdamAtlanta: Rodopi.

Nord, Christiane. 1997. Translating as a purposeful activity. Manchester: St Jerome.

Northcott, Jill, and Gilian, Brown. 2006. Legal Translator Training: Partnership between Teachers of English for Legal Purposes and Legal Specialists. English for Specific Purposes 25(3): 358-375.

(online:

https://edinburgh.academia.edu/JillNorthcott)

Orlando, Daniele. 2015. The Trials of Legal Translation Competence: Triangulating Processes and Products of Translators vs. Lawyers. PhD Thesis. (online: https://arts.units.it/retrieve/handle/11368/2908045/187217/OR LANDO_PhD_Thesis.pdf)

Prieto Ramos, Fernando. 2011. Developing Legal Translation Competence: An Integrative Process-Oriented Approach. 
Comparative Legilinguistics - International Journal for Legal Communication 5: 7-21.

Prieto Ramos, Fernando. 2015. Quality assurance in legal translation: evaluating process, competence and product in the pursuit of adequacy. International Journal for the Semiotics of LawRevue internationale de Sémiotique juridique 28(1): 11-30.

Šarčević, Susan. 1997. New Approach to Legal Translation. The Hague: Kluwer Law International.

Stemler, Steven E., and Jessica, Tsai. 2008. Best practices in interrater reliability: Three common approaches. In Best practices in quantitative methods. ed. Osborn, Jason W. 29-49. Thousand Oaks: SAGE Publications.

Trosborg, Anna. 1997. Translating Hybrid Political Texts. In Text Typology and Translation, ed. Anna Trosborg, 145-158. Amsterdam: John Benjamins.

\section{Appendix 1. The source text (segment)}

\section{ART.5: PERFORMANCE OF THIS CONTRACT - GUARANTEES AND RESPONSIBILITY}

Without prejudice to the fact that by entering into this contract HOTEL RESORT exclusively assumes full responsibility towards DOLCE VITA for correctly and punctually fulfilling all the obligations bestowed upon it, it is agreed that HOTEL RESORT is fully entitled to proceed, entirely or in part, to undertake the work mentioned above through subjects that it singles out and selects.

In particular, HOTEL RESORT may, by way of example:

- carry out the works covered by this assignment directly or through subcontracted firms or suppliers;

- delegate to other companies, fully or in part, the execution of ancillary services related to the execution of the work and the supplies, to this end establishing Italian and/or foreign companies, setting-up foreign branches etc.

The foregoing will not however release HOTEL RESORT from its obligations towards DOLCE VITA, constituting a mere 
method to implement the obligations set forth in this Deed, for which HOTEL RESORT remains the sole and exclusive subject responsible towards DOLCE VITA, and for this reason, in no case whatsoever may the former avoid responsibility for any breaches, even if caused by the acts and behaviour of subjects to whom it delegates the execution of activities and services covered by this contract. Equally, in the event that HOTEL RESORT avails itself of third party services, said third parties will not be able to make any claims against DOLCE VITA, since it has been established that HOTEL RESORT alone will have obligations towards them, as it is not authorised to take on obligations in the name or on behalf of DOLCE VITA.

The Parties acknowledge once again that this framework agreement, already binding for them, will be implemented through specific deeds, which also have the supplementary function of determining the details of the project, which may also be carried out in a number of phases, taking into account the need to accelerate the execution times and the availability of the plans.

Irrespective of the nomination of subjects who will implement this agreement, the Parties will be directly responsible for each obligation which is assumed through this Deed and which is defined through the subsequent implementation contracts, and will be reciprocally responsible, in respect to one another, for any breaches by nominated third parties, as if these breaches were directly attributable to them.

\section{ART. 6: PAYMENT OF THE REMUNERATION}

The remuneration for the execution of the work and supplies set forth in the project, which will be approved by DOLCE VITA in accordance with art.4 above, for the amount which will be determined therein, shall be paid to HOTEL RESORT in accordance with the following methods and deadlines, even in the case set forth in the last paragraph of the aforesaid art. 4:

- Down payment of $30 \%$ of the total contracted amount.

- Monthly progress reports.

- Final balance after final inspections.

- $10 \%$ as a guarantee by means of insurance guarantee.

The Parties reserve the right, on the basis of the abovementioned principles, to determine these methods in greater detail upon approval of the project, it being understood, however, that the 
payment of the remunerations shall take place in such a way that HOTEL RESORT does not have to advance payments to its own subcontractors and/or suppliers.

The payment of remunerations due to HOTEL RESORT shall be adequately guaranteed by DOLCE VITA and by companies that it may nominate, in order to guarantee the certainty of the supply. 